\section{Applying master curve at the grids strengthened asphalt structures}

\author{
KornÉl ALMÁSSY, MSc. - Department of Highway and Railway Engineering - kornel.almassy@gmail.com \\ Csaba TÓTH, Msc. - Department of Highway and Railway Engineering - toth@uvt.bme.hu \\ Received: 26.08.2010. - Érkezett: 2010.08.26. http://dx.doi.org/10.14382/epitoanyag-jsbcm.2011.3
}

The master curve is an appropriate tool to describe the behavior of the different asphalt mixtures. We can analyze the attitude of the asphalt at very special time and frequency range using master curve method and in this extreme condition we could not solve without it. Different shift coefficients calculation's methods were showed in this study. According to a Dutch (Sigmoid) method, the slope of the master curve determines the fatigue characteristic of the asphalt mixture. In this article we analyze and compare the master curves of the grid strengthened and non grid asphalt structures.

Keywords: asphalt mixtures, master curve, grids, shift factor, stifness

\section{Introduction}

In the last decade the era of build in mesh and grid in asphalt pavement commenced. In this period different types and qualities of mesh were built into asphalt reconstructions in Hungary with little technological experience and quality control. The Department of Road and Railway Building at Budapest University of Technology and Economics started a research about applying grids in asphalt pavement five years ago. One part of the research work is dealing with a special method of asphalt laboratory testing called the master curve. The master curve is an appropriate tool to describe the behaviour of different asphalt mixtures. This study is aimed to determine the master curve of a grid strengthened asphalt structure as a special parameter. Under extreme conditions a good comparison of the behaviours of the grid strengthened and non-strengthened asphalt structures was found. (As we know, this was the first time when master curves were determined for $\mathrm{grid} / \mathrm{mesh}$ strengthened asphalt specimens.)

\section{Processing test results by means of master curves}

\section{a. Time-temperature similarity principle}

It is commonly known that the behaviour of - one of the most used construction materials - the asphalt mixture greatly depends on the load character and the test temperature. Determination of stiffness values at different temperatures and load levels characterizes the material behaviour however, there is no simple method to evaluate the values. In Hungary the usual processing method of stiffness values is obtained to present them according to isotherms; however, this is less suitable for demonstrating the differences between mixtures.

Thus, during evaluation we also wanted to find in which other forms the results of the stiffness tests carried out at different temperatures and loads. Having reviewed the international literature, it became obvious that the temperature-time similarity principle of rheology could be a well suited tool for studying the behaviour of asphalt mixtures.

The similarity of the form of temperature modulus and time modulus lets conclude that both temperature and time cause rheological changes in the same direction; this makes both quantities convertible into each other $[1,2]$.
Dr. Kornél ALMÁSSY

graduated in 1999 at Budapest University of Technology and Economics, Faculty of Civi Engineering and in 2002 at Faculty of Economic Science (Master of Business Administration MBA). He was Chairman of the National Student Union of Hungary (2001-2003), Chairman of the Youth Democratic Forum (Youth of the Hungarian Democratic Forum) (2004-2006) and ViceChairman of the Hungarian Democratic Forum (2004-2008). He was Member of the Hungarian Parliament (2006-2010). Now he is the director of road maintenance departement of the Metropolitan Public Space Maintenance Company.

Dr. Csaba Tóth graduated in 1997 at Budapest University of Technology and Economics and in 2008 at Quality and Production Management (Master of Business Administration - MBA). He is manager of Makadám 2000 Úttervezō Mérnök Iroda since 2000. He is Assistant Professor at Budapest University of Technology and Economics Department of Highway and Railway Engineering. His main fields of interest is the road pavement structure designing.

According to this principle, as the elasticity modulus is a function of testing time $(t)$ and testing temperature $(T)$, a certain modulus $\mathrm{E}\left(T_{1} ; t_{1}\right)$ determined at a temperature $\left(T_{1}\right)$ and a load time $\left(t_{1}\right)$ can be converted to a given reference temperature $\left(T_{2}<\right.$ $\left.T_{1}\right)$ and a time $\left(t_{2}>t_{1}\right)$ dependent on that temperature. The basic mathematical relation of the principle is as follows:

$$
E\left(T_{1}, t_{1}\right)=E\left(T_{2}, t_{2}\left(T_{1}, T_{2}\right)\right)=E\left(T_{2}, \frac{t_{1}}{a_{T}}\right)
$$

where $\left(\mathrm{a}_{\mathrm{T}}\right)$ is the so-called temperature-time shift coefficient:

$$
a_{T}=\frac{t_{1}}{t_{2}\left(T_{1}, T_{2}\right)}
$$

indicating a shift in logarithmic time scale.

$$
\log _{2}\left(T_{1}, T_{2}\right)=\log t_{1}-\log a_{T}
$$

Knowing this shift coefficient, the common illustration and evaluation of the modulus time and modulus temperature relations can be established by means of so-called master curve.

With the assistance of master curve, it is possible to jointly present the measured isotherms, handle them together and compare mixtures in a more complex way.

\section{b. The shift factor of Arrhenius}

The domestic regulation is considerably succinct regarding the master curve determination. The standard MSZ EN 1269726 on Asphalt Mixtures; Test Methods for Hot Mix Asphalt. Part 26: Stiffness [3] describes the principle of determining the master curve generally. Master curve at a given temperature has to be determined by shifting the isotherms plotted at other temperatures strictly parallel to the axle of the load duration only. The determination of the value of the shift coefficient is not described in the standard.

Based on data from the literature, we chose the shift coefficient according to the relation of Arrhenius. The Arrhenius Law refers in its original form to the dependence of chemical reactions from temperature, but it is used in the rheology to determine the shift coefficient in the following form: 


$$
\log a_{T}=\log e \frac{\Delta H}{R}\left(\frac{1}{T}-\frac{1}{T_{r e f}}\right)=C\left(\frac{1}{T}-\frac{1}{T_{\text {ref }}}\right)
$$

where

$a_{T}=$ shift coefficient

$T=$ test temperature $(\mathrm{K})$

$T_{\text {ref }}=$ reference temperature $(\mathrm{K})$

$C^{r e f}=$ constant $(\mathrm{K})$

$\Delta H=$ activation energy $(\mathrm{J} / \mathrm{mol})$

$R=$ universal gas constant, $8,314 \mathrm{~J} / \mathrm{mol} \mathrm{K}$

As for the constant $(C)$ to be used for asphalt mixtures, some data can be found in the international literature [4]. Francken, based on his tests with bitumen and asphalts, proposed a value of $50 \mathrm{kcal} / \mathrm{mol}$ for the activation energy, which yields a value of $(10920 \mathrm{~K})$ for the constant $(C)$. Others, e.g. Lytton et al and Jacobs (1995) proposed the values $(C=13030 \mathrm{~K})$ and $(C=7680 \mathrm{~K})$, respectively.

\section{c. Sigmoid model}

Consequently, knowing the shift coefficient, we have to determine the master curve related to a given temperature, by shifting the isotherms plotted at other temperatures. However, this means determining one discrete series of points only; it is useful, if we could describe it in form of some function relation to be able to analyze at a later time. This used to be achieved by means of polynomials earlier.

Related to the tested mixtures, we used the shift coefficient of Arrhenius when determining the master curves and fitted a function of sigmoid form (1) onto the received point series.

$\log \left|E^{*}\right|=\delta+\frac{\alpha}{1+e^{\beta-\gamma \log f_{r}}}$

where

$\mathrm{E}^{*} \quad=\quad$ complex modulus $(\mathrm{MPa})$

$\alpha, \beta, \delta, \gamma=\quad$ constant parameters characterizing the mixture

$\mathrm{f}_{\text {red }} \quad=\quad$ reduced frequency $(\mathrm{Hz})$

The parameters of the function which describes the relation between stiffness and load - at a specific reference temperature - can be determined by the so-called simultaneous optimization technique. In essence, this method simultaneously changes the shift coefficient and the sigmoid model parameters, while we try to find the function that best fits to the measurement points. However, this search for the optimum values can be performed relatively simply by using the solver module of Excel.

By also treating the parameter $(C)$ of the shift coefficient as a variable, the master curves determined at $20^{\circ} \mathrm{C}$ are shown in Fig. 1.

\section{Master curve of the grid strengthened and non grid asphalt specimens}

\section{d. Testing and evaluation}

To determine the master curve we use the method of the 4 point bending beam test, but only still the 100 cycle, when we read the starting stiffness of the asphalt structure. For the testing we used two layer asphalt specimen made by AC-11 without any grid and two layer asphalt specimen also made by AC-11 strengthened with GlasGrid 8502 asphalt grid.

With the definition of the master curve we were curious for stiffness differences of the grid reinforced and unreinforced specimen's value. We would like to know when to start work the grid, to set forth positive impact. Fig. 1. shows the master curves of the specimens with and without grids. (KH means specimens with grids and KR means reference specimens without any grids.)

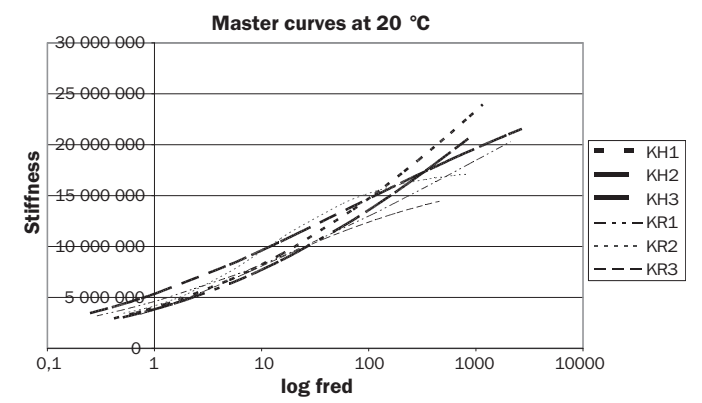

Fig. 1. Master curves at $20{ }^{\circ} \mathrm{C}$ for strengthened and normal specimens (without grids)

1. ábra A rácserősitésü és rács nélküli próbatestek mestergörbéi $20^{\circ} \mathrm{C}$-on (KH jelü: rács, KR jelü: referencia)

In Fig. 1. the stiffness of the asphalt structure increase at the higher frequency range for the benefit of the reinforced specimen. At medium frequency level the grid reinforced specimen has the same stiffness value like the unreinforced sample.

Dissection of the master curves justified our previous test experience - wheel tracking and bending test - that at the lower quality asphalt mixture get on lot better the impact of the stiffer asphalt grid.

\section{References}

[1] Tóth, S. (2000): Rheology, Rheometry. Publishing House of the University of Veszprém

[2] Bodor, G. - Vas, L. M. (2005): Polymer Material Science. Publishing House of the Technical University

[3] MSZ EN 12697-26

[4] Medani, T. O. - Huurman, M. (2003): Constructing the Stiffness Master Curves for Asphaltic Mixes. Report 7-01-127-3 ISSN 0169-9288. Delft University of Technology

[5] Almássy, K. - Joó, A. L.: Special materials in the road building - Grids and netts application terms for improving the pavement structures. Építöanyag, 2009/2, pp 55-59.

Ref.: http://dx.doi.org/10.14382/epitoanyag-jsbcm.2011.3

Kornél Almássy - Csaba Tóth: Applying master curve at the grids strengthened asphalt structures. Építőanyag, 63. évf. 1-2. szám (2011), 16-17. p.

Mester görbék alkalmazása a rácserősítésű aszfaltszerkezeteknél

A mester görbék nagyon pontos leírást adnak a különbözô aszfaltkeverékek tulajdonságairól. A mestergörbék meghatározásával olyan idô és frekvencia tartományokban vizsgálhatjuk az aszfaltok viselkedését, amelyet kísérletileg nem, vagy csak nagyon nehezen lehetne megoldani. A mestergörbék meghatározásához szükséges úgynevezett eltolási tényezô kiszámítási módszereit mutatjuk be a tanulmány során. Egy holland, úgynevezett Szigmoid eljárással meghatározott mestergörbék meredeksége fontos információt ad az aszfaltkeverékek tönkremeneteli karakterisztikájával kapcsolatban. A cikkben a rácserôsítéssel, illetve anélkül készült aszfaltszerkezetek mestergörbéit elemezzük és hasonlítjuk össze. Kulcsszavak: aszfalt keverékek, mester görbe, rács, eltolási tényezô, merevség 